\title{
Reconstructions of Paleoecological and Paleoclimatic Conditions of the Late Pleistocene and Holocene according to the Results of Chironomid Analysis of Sediments from Medvedevskoe Lake (Karelian Isthmus)
}

\author{
L. B. Nazarova ${ }^{a, b}, * *$, D. A. Subetto ${ }^{c, d}$, L. S. Syrykh ${ }^{b, d}, *$, I. M. Grekov ${ }^{d}$, and P. A. Leontev ${ }^{d}$ \\ Presented by Academician A.P. Lisitsyn October 19, 2015
}

Received February 21, 2018

\begin{abstract}
The use of chironomids (Diptera: Chironomidae) as indicators of changes in natural and climatic settings allows one to reconstruct paleoclimatic and paleoenvironmental conditions. Based on the results of lithological and chironomid analyses, the loss on ignition (LOI) values, as well as the results of radiocarbon dating $\left({ }^{14} \mathrm{C}\right.$ AMS $)$, new data on the paleoclimate in the Karelian Isthmus, in particular the quantitative reconstruction of the mean July temperature $\left(T_{\mathrm{July}},{ }^{\circ} \mathrm{C}\right)$ in the Late Pleistocene and Holocene and the evolution of the ecosystem of Medvedevskoe Lake have been obtained.
\end{abstract}

DOI: $10.1134 / \mathrm{S} 1028334 \mathrm{X} 18060144$

Climatic processes during the Late PleistoceneHolocene transition in the area of the Karelian Isthmus have been previously studied in detail [1-5]; however, data on the paleoclimate in the Holocene in this region are scarce [6].

Deglaciation of the Karelian Isthmus occurred during the retreat of glaciers at the Luga and Neva stages of the Upper Valdai Glacial [4]. The central part of the Karelian Isthmus became open from ice before $13.6 \mathrm{ka}$ and represented a hill (nunatak) above the glacier surface with small inland lakes [1], the study of which is of particular importance, since they are characterized most likely by continuous sedimentation in comparison with other areas of the Isthmus, which were repeatedly flooded by the waters of the Baltic Sea and Lake Ladoga [1].

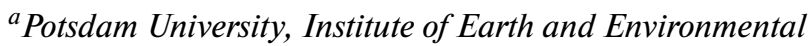
Science, Potsdam, Germany

${ }^{b}$ Kazan Federal University, Kazan, 420008 Russia

${ }^{c}$ Northern Water Problems Institute, Karelian Science Center, Russian Academy of Sciences, Petrozavodsk,

Republic of Karelia, 185003 Russia

${ }^{d}$ Herzen Russian State Pedagogical University,

St. Petersburg, 191186 Russia

*e-mail: lyudmilalsd@gmail.com

**e-mail: Larisa.nazarova@awi.de
Our study aimed to reconstruct the paleoecological and paleoclimatic conditions in the Karelian Isthmus during the Late Pleistocene and Holocene based on the data on the organic matter content and the results of biological analysis of bottom sediments from Medvedevskoe Lake. Chironomids (Diptera: Chironomidae) and statistical models based on extensive databases on ecological parameters and the taxonomic composition of chironomids of lakes of Northern Russia were used as an indicator group [7, 8].

In the spring periods of 2012 and 2014, two cores of bottom sediments (BS) were collected on Medvedevskoe Lake $\left(60^{\circ} 31^{\prime} 51^{\prime \prime} \mathrm{N}, 2^{\circ} 53^{\prime} 57^{\prime \prime} \mathrm{E}, 102.2 \mathrm{~m}\right.$ a. s. 1 , an area of $0.44 \mathrm{~km}^{2}$, maximum depth of $4 \mathrm{~m}$ ) (Fig. 1). The samples of sediments were analyzed using the loss on ignition (LOI) method to estimate the organic matter and carbonate content in lacustrine sediments (LOI, \%) [9] and were dated using accelerator massspectrometry $\left({ }^{14} \mathrm{C}\right.$ AMS $)$. According to the radiocarbon data analysis and the LOI values, a BS composite column was compiled.

Chironomid analysis was performed following the standard procedure [10]. Reconstruction of the paleoecological conditions and the mean July air temperature $\left(T_{\text {July }}\right)$ was performed using the Northern Russian chironomid-based data set and inference models [11]. Percentage stratigraphic diagram was made in $\mathrm{C} 2$ version 1.5 [12]. Cluster analysis and the principal com- 


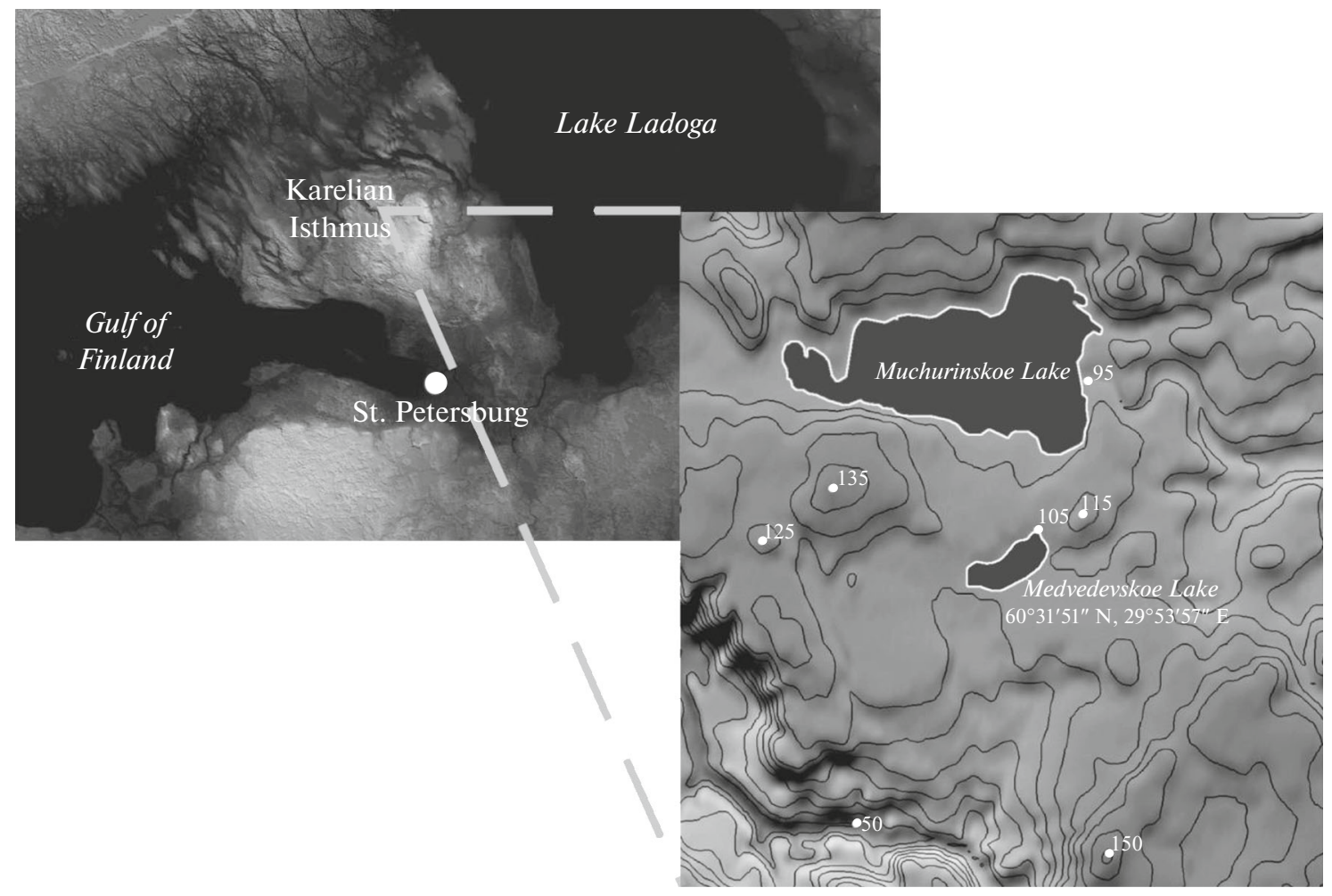

Fig. 1. The locality of Medvedevskoe Lake on the Karelian Isthmus.

ponent method (PCA) were performed using the PAST program software [13].

\section{RESULTS}

The bottom sediments of Medvedevskoe Lake are represented by Late Glacial gray sands, clays, and Holocene dark-brown organogenic silt. The age of sediment cores covers the Late Glacial and Holocene. The microscopic glass from the Vedde volcanic ash (12 ka) $[5,14]$ and traces of a meteorite impact that happened about 12.9 ka ago were identified [5]. Cluster analysis made it possible to distinguish four statistically significant zones, which are well correlated with the PCA 1 axis, reflecting variations in the taxa composition of chironomids.

Zone 1 (460-496 cm; 12.1-10.2 ka). LOI values are extremely low (median value $7.0 \%$ ). Low-temperature taxa predominate (Micropsectra insignilobustype, Sergentia coracina-type, Heterotrissocladius maeaeri-type 1, Zalutschia type B). Acidophilic ( $S$. coracina-type, H. maeaeri-type 1, Psectrocladius sordidellus-type), or acidophobic (M. insignilobus-type) taxa are alternately dominated. Smittia a taxon associated with erosion processes, was found in the lower horizons.

The reconstructed $T_{\text {July }}$ varied from 12 to $14 \pm 1.1^{\circ} \mathrm{C}$ (mean value $13.0^{\circ} \mathrm{C}$ ).
Zone II (420-460 cm; 10.2-8.5 ka). LOI values gradually increase (median value $23.7 \%$ ); the species diversity increases, and the complex of dominant chironomid species changes. Oligotrophic $S$. coracinatype, $M$. insignilobus-type, and $H$. maeaeri-type 1 disappear. Corynocera ambigua dominates. There was the first occurrence of the Microtendipes pedellus-type, which is regarded as an indicator of moderate temperatures [10] and an increase in the number of phytophilic taxa (Dicrotendipes nervosus-type, Zalutschia zalutschicola, etc.). The $T$ July temperature varied from 12.5 to $15.0 \pm 1.1^{\circ} \mathrm{C}$ (mean value $13.8^{\circ} \mathrm{C}$ ).

Zone III (340-420 cm; 8.5-3 ka). LOI values are maximal (median $72.7 \%$ ). The number of C. ambigua decreases, while that of the $M$. pedellus-type and $D$. nervosus-type increases. The first occurrence of Procladius indicates an increase in trophicity and a decrease in the amount of dissolved oxygen [10]. After 4 ka there was a decrease in the amount of the thermophilic $M$. pedellus-type and D. nervosus-type and an increase in cold-water Heterotanytarsus. The temperature in July $\left(T_{\text {July }}\right)$ varied from 13.7 to $15.2 \pm 1.1^{\circ} \mathrm{C}$ (mean value $14.5^{\circ} \mathrm{C}$ ).

Zone IV (260-340 cm; after $3 \mathrm{ka})$. The LOI values are high (median value $78.8 \%$ ); in the upper horizon, a decrease to $42.8 \%$ was recorded. The fauna is characterized by a predominance of the thermophilic $D$. nervosus-type and the acidophilic $P$. sordidellustype. In the middle of the zone, Heterotanytarsus, 


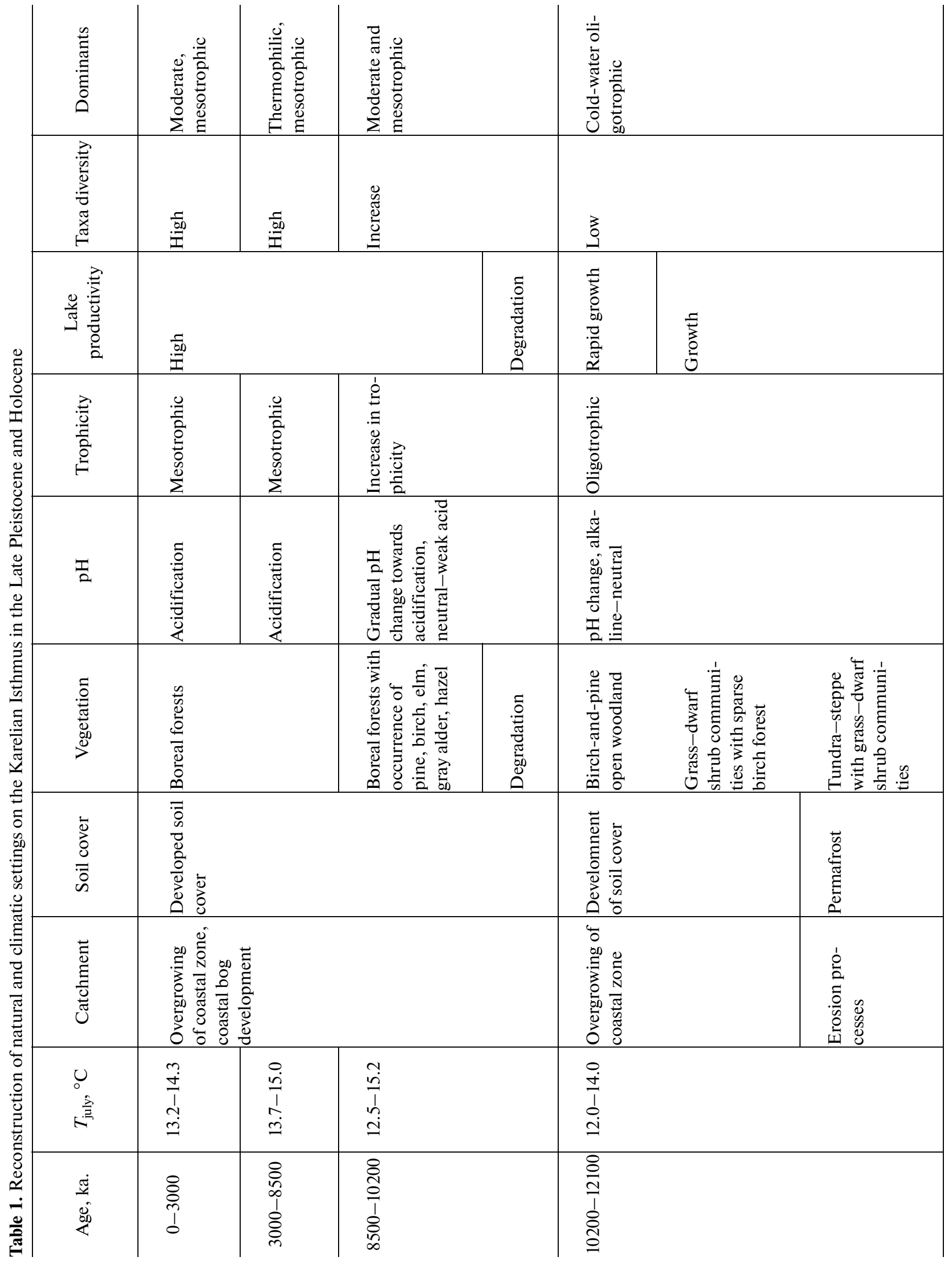




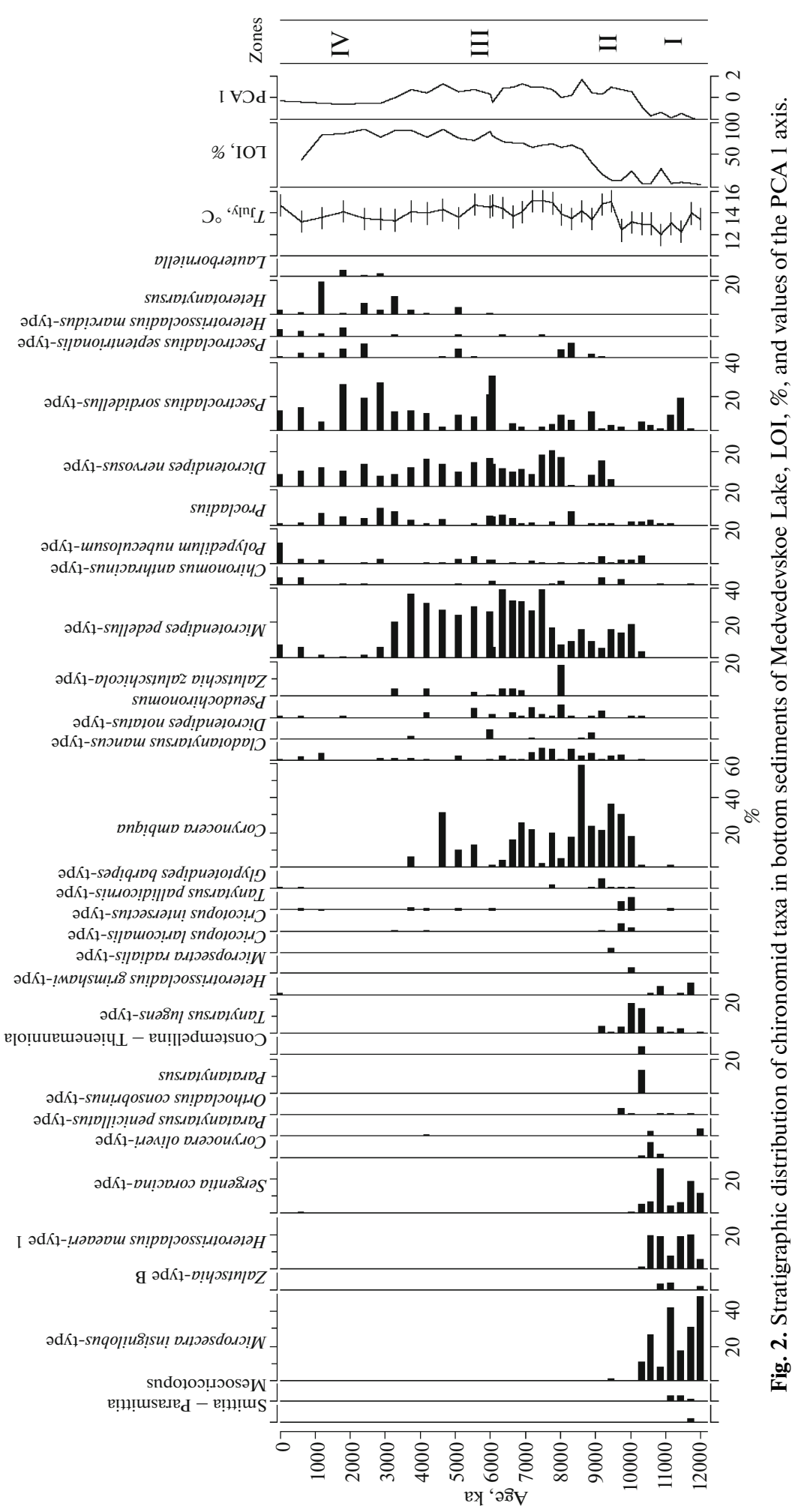


associated with oligotrophic humic waters, was identified. $T_{\text {July }}$ varied from 13.2 to $14.3 \pm 1.1^{\circ} \mathrm{C}$ (mean value $\left.13.6^{\circ} \mathrm{C}\right)$.

\section{DISCUSSION}

Prior to $12.65 \mathrm{ka}$, the climate in the Karelian Isthmus was arctic, cold, and dry. The central high represented an island washed by the cold waters of the Baltic glacial lake. Medvedevskoe Lake was shallow and was not clear of ice every year [1, 4].

During the Late Glacial-Holocene transition, the development of the lacustrine ecosystem started (Table 1) (12.1-10.2 ka). The predominance of coldwater taxa and the extremely low LOI values indicate that in this period the water reservoir remained oligotrophic under cool climatic conditions (Fig. 2). The occurrence of semi-aquatic taxa and the changes in acidophilic and acidophilic dominants indicate the instability of the lake level, which was dependent on the amount of precipitation and permafrost thaw, causing bogging of the coastal zone and the supply of humic acids from the catchment area [15].

After 10.2 ka significant changes in biological communities and a gradual increase in the content of organic carbon in bottom sediments $\left(\mathrm{C}_{\text {org }}>20 \%\right)$ occurred. Cryophilic taxa were replaced by inhabitants of waters with moderate and mesotrophic conditions. The climate became warmer; the surface runoff intensity decreased, and the lake trophicity increased.

The warm climatic conditions did not change throughout the entire period from 9 to $4 \mathrm{ka}$, which could be associated with the Holocene Climate Optimum. After $4 \mathrm{ka}$ there was some cooling; at about $3000 \mathrm{ka}$, the climatic conditions became close to modern ones.

\section{ACKNOWLEDGMENTS}

Chironomid analysis was supported by the Russian Science Foundation, project no. 16-17-10118. Field work was supported by the Russian Foundation for Basic Research, project no. 13-05-41457 RGO_a.

\section{REFERENCES}

1. D. A. Subetto, Lake Sediments: Palaeolimnological Reconstructions (Herzen State Pedagogical Univ. of Russia, St. Petersburg, 2009) [in Russian].

2. The History of the East European Plain Lakes, History of Lakes (Nauka, St. Petersburg, 1992) [in Russian].

3. D. A. Subetto, N. N. Davydova, T. V. Sapelko, B. Wohlfarth, S. Wastegård, and G. Possnert, Izv. Russ. Geogr. O-va 134 (1), 47-64 (2002).

4. D. A. Subetto, N. N. Davydova, T. V. Sapelko, B. Wohlfarth, S. Wastegård, and D. D. Kuznetsov, Izv. Ross. Akad. Nauk, Ser. Geogr., No. 5, 80-91 (2003).

5. A. V. Andronikov, D. A. Subetto, D. S. Lauretta, I. E. Andronikova, D. A. Drosenko, D. D. Kuznetsov, T. V. Sapelko, and L. S. Syrykh, Dokl. Earth Sci. 457 (1), 819-823 (2014).

6. Kh. A. Arslanov, L. A. Saveljeva, N. A. Gey, V. A. Klimanov, S. B. Chernov, G. M. Chernova, G. F. Kuzmin, T. V. Tertychnaya, D. A. Subetto, and V. P. Denisenkov, Radiocarbon 41, 25-45 (1999).

7. L. Nazarova, U. Herzschuh, S. Wetterich, Th. Kumke, and L. Pestjakova, J. Paleolimnol. 45, 57-71 (2011).

8. L. Nazarova, V. De Hoog, U. Hoff, and B. Diekmann, Quat. Sci. Rev. 67, 81-92 (2013).

9. J. I. Santisteban, R. Mediavilla, E. López-Pamo, C. J. Dabrio, M. B. R. Zapata, M. Blanca, M. J. G. García, S. Castaño, and P. E. Martínez-Alfaro, J. Paleolimnol. 32 (3), 287-299 (2004).

10. S. J. Brooks, P. G. Langdon, and O. Heiri, QRA Technical Guide No. 10 (Quat. Res. Ass., London, 2007).

11. L. Nazarova, A. Self, S. J. Brooks, M. van Hardenbroek, U. Herzschuh, and B. Diekmann, Global Planet. Change 134, 10-25 (2015).

12. S. Juggins, C2 Version 1.5 User Guide. Software for Ecological and Palaeoecological Data 44. Analysis and Visualization (Newcastle Univ., Newcastle upon Tyne, 2007).

13. O. Hammer, D. A. T. Harper, and P. D. Ryan, Palaeontol. Electron. 4 (1), 9 (2001).

14. S. Wastegård, B. Wohlfarth, D. A. Subetto, and T. V. Sapelko, J. Quat. Sci. 15 (6), 581-586 (2000).

15. B. Wohlfarth, T. Lacourse, O. Bennike, D. A. Subetto, I. Demidov, L. Filimonova, P. Tarasov, and T. Sapelko, Quat. Sci. Rev., No. 26, 1871-1883 (2007).

Translated by D. Voroshchuk 